\title{
Antecedents of Word-of-mouth towards professional B2B service
}

\author{
Mai Ngoc Khuong ${ }^{\mathrm{a}, \mathrm{b}}$, Nguyen Xuan Nhi ${ }^{\mathrm{c}^{*}}$, Le Thi Thao Linh ${ }^{\mathrm{a}, \mathrm{b}}$
}

${ }^{a}$ School of Business, International University, Ho Chi Minh City, Vietnam
${ }^{b}$ Vietnam National University, Ho Chi Minh City, Vietnam

${ }^{c}$ Faculty of Business Administration, Nguyen Tat Thanh University, Vietnam

\section{H R O N I C L E}

\section{Article history:}

Received: October 14, 2020

Received in revised format:

November 112020

Accepted: November 14, 2020

Available online:

November 14, 2020

Keywords:

Word-of-mouth

B2B Professional Services

General Insurance

\section{A B S T R A C T}

This research was conducted to investigate the antecedents directly and positively affecting organization's word-of-mouth towards professional service, primarily in the context of B2B professional general insurance services in Vietnam. The empirical results of this research indicated that five out of seven factors, namely interpersonal skills, premium, technical skills, reputation and risk coverage had both significantly positive direct and indirect effects on organization's word-of-mouth with the mediation role of organization's perceived service quality. Based on the empirical results, it is suggested that insurers should improve organization's perceived service quality, and thereby enhance their word-of-mouth behavior.

\section{Introduction}

The Vietnamese insurance industry experienced rapid growth during the period 2014-2018 with an average $16 \%$ growth rate, wherein the non-life insurance sector increased by $11.7 \%$. The total premiums of the whole market reached USD 6.93 billion with general insurance premiums reached USD 2.26 billion in 2019, representing a 20.5\% improvement in one year. Notwithstanding, insurance industry in Vietnam faces many challenges. The level of insurance penetration in Vietnam is about $2 \%$ of GDP, notably lower than the rate observed in ASEAN (3.55\%), Asia (5.37\%) globally (6.3\%). Whilst according to Insurance Association of Vietnam, Vietnamese people have awareness about insurance service, rates of insurance take up are low. Several factors are believed responsible for this growth rate, including the price restrictions, competitive pricing pressures and rising claims. Combined with pursuit of new business and online distribution channels, this generates cost reductions, generating efficiency beyond the reach of the traditional agent. Business-to-business (B2B) marketing has been studied in the last three decades, some areas have been studied thoroughly, including word-of-mouth (WOM) conceptuality, while further exploration and research are still required for the others. While today customers trust less in advertisements, WOM has become an influential source of information, especially in services, because it is difficult to measure the quality or performance of intangible products. Providing comments, feedback and opinions can be among the most persuasive and impartial referrals in the marketplace (Sweeney et al., 2008). WOM is also a critical component of decision-making process, including attitudes, perceptions, preference, purchase behavior and repurchase intention (Clemes et al., 2014). Moreover, the service quality concept appears in a vast majority of studies involving the level of customer satisfaction, customer perceived quality and value that lead to the customer behavioral intentions, improvement in business performance and competitive advantage for an organization (Khajeheian, 2016). Having reviewed the literature and results of previous studies, this research was conducted to test the direct effects of explanatory variables on perceived service quality (PSQ) and WOM in professional B2B general insurance industry in Vietnam, and explore the indirect effects of those variables on WOM with mediation role of PSQ. Consequently, a new measurement scale could be built based on the revision of previous research results, and additional

* Corresponding author.

E-mail address: nxnhi@ntt.edu.vn (N. X. Nhi) 
findings in the general insurance industry in Vietnam, because an in-depth insight into the antecedents of WOM and the correlations between WOM and other factors may significantly contribute to the development of professional insurance service providers.

\section{Literature review}

\subsection{Word-of-mouth}

During the recent decades, WOM conceptuality and WOM marketing programs have been the common considerable topics in academic literature and management practice (Haenlein \& Libai, 2017). Moreover, WOM also naturally and frequently appears in daily conversations between people who are familiar and credible to each other, therefore, WOM produces reliable and convincing messages (Jalilvand et al., 2017). In fact, WOM is the significant factor affecting 20 to 50 percent of customers' purchasing decisions (McKinsey, 2020). In B2B contexts, WOM communication has been widely recognized and accepted as a significantly critical influence on purchase decisions of organization customers due to characteristics of service industry, including high risk, intangibility, inseparability and non-standardization (Mokhtaran et al., 2015). WOM is the communication involving the evaluation of a customer who experienced products or services with a potential customer (Silverman, 2011). WOM occurred in the final stage of consuming products or services that consumers share reliable messages to target audience to persuade other people to use the products or services and affect listeners' attitudes, intentions and behaviors (Hawkins \& Mothersbaugh, 2010). WOM can also be described as positive commentary, persuasive referrals and influential advice from people who have experienced products or services to people who are interested in experiencing those products or services (Zhao \& Xie, 2011). In the context of this research, WOM is concerned as the consequence of organization's perceived service quality (OPSQ) so that the organization customers play the communicator role to recommend to others professional general insurance services. Therefore, a suitable definition of WOM for this research is the oral communication and informal conversations with non-commercial contents that exchange information, comments, thoughts and recommendations about the evaluations of products, services, brand names and providers between organization customers to other business associates. With the development of Internet platform, WOM takes another form of electronic word-of-mouth (eWOM), which is defined as positive or negative feedback of customers who use social networking sites (Davis \& Khazanchi, 2008). Research of Fong \& Burton (2008) showed that eWOM is more effective than in WOM in today's marketing thanks to its ease of use and popularity. WOM behavior and online review are highly valued by B2B enterprises that help spread information more efficiently, encourage repurchase from current customers and entice new customer purchase, and result in sales growth and increased revenues (Habibi et al., 2015).

\subsection{Perceived Service Quality}

Plenty of researchers have continually studied on different aspects and issues of service quality definition, conceptualization, models, measurement scales, data collection procedures, data analysis, etc., that created a platform for the following researchers to expand the scope of concerns and deepen the research subjects (Seth et al., 2005). Service quality has been studied in various field and sector of service industry from banks, insurance, hospitality, travel and tourism to government and public services, IT and software and advertising (Chawla \& Sharma, 2017). Generally, perceived service quality is defined by two bases according to the way it is measured: perceptions versus expectations, or personal attitude and evaluation. From "customer's attitude" perspective, perceived service quality is the consumer's evaluative judgment regarding the superiority of service performance (Wilson et al., 2016). Nyadzayo and Khajehzadeh (2016) also defined perceived service quality as the overall judgment of customers on the performance of a service provider. It indicates not only the level of customer satisfaction but also the ability of a company to determine customer expectation because customers are likely to repurchase or introduce a service company that meets or exceeds their expectation. From perspective of perceptions - expectations, perceived service quality is an eminently cognitive construct, which values the result, where expectations are compared to the result (Sánchez et al., 2006). In this study, PSQ is considered as the result of seven specialized factors and as a mediated factor that together lead to WOM behavior. Therefore, PSQ can be demonstrated by the gap between perceptions and expectations as it shows the comparison process of organizations' expectations towards service offered and performance of service providers in reality (Tan et al., 2010). In the literature of service industry and marketing field, Alexandris et al. (2002) and Hutchinson et al. (2009) found that PSQ has both direct and indirect influences on post behaviors of WOM communication. For the indirect relationship among PSQ and behavioral intentions or outcomes such as WOM, customer satisfaction commonly plays the role of mediation factor (Parasuraman et al., 1985; Zeithaml et al., 1996). In the current studies, scholars have also proven the strong correlation between antecedent customer satisfaction and behavioral outcomes customer loyalty (Donio' et al., 2006), repurchase intention and WOM (Cronin et al., 2000). Therefore, it can be seen that the chain "Service Quality $\rightarrow$ Satisfaction $\rightarrow$ Word-of-mouth" has been popular in both classical and modern literature of service industry.

\subsection{Antecedents of WOM}

\section{Interpersonal skills}

Traditional approach of B2B marketing has proved the important roles of interpersonal communications and relationships between sales representatives and organizations (Huotari et al., 2015). Interpersonal skills in personal interaction are the key 
element in evaluating the quality in various types of service because employees' knowledge, efficiency, competency, approachability, courteousness, politeness, willingness to help, pleasantness and politeness are factored into service quality evaluation (Brady \& Cronin, 2001; Yang et al., 2004). Besides, service staffs with good interpersonal skills can provide excellent experience to customers and influence customer positive WOM (Zhang et al., 2016). Interpersonal skills are demonstrated as the helpful ability in business communication such as listening skills, relationship building, perceptive observation skills, empathy, optimism and the abilities to control the situation and solve problems (Hébert \& Hauf, 2015; Roth et al., 2008). Klein et al. (2008) divided interpersonal skills into two dimensions relating to the purposes of communication; namely building and maintaining relationships by helping and supporting others, whilst exchanging, gathering or transmitting information. In this research context, the suitable definition of interpersonal skills is listening skills, the ability to understand the situation and solve problems, whilst maintaining good attitude towards the customer, displaying professionalism, empathy, harmonious, willingness, politeness, etc.

\section{Technology}

Customer satisfaction and perceptions of service quality have been found to increase through the technology adoption such as how internet-based technology can respond to customers' inquiries or implement their requests, how information technology applications can be used to help customers solve their problems in timely manner (Lee et al., 2007). Technology was proved to have positive relationship with WOM in B2B marketing by spreading widely at a rapid pace with web-based applications and deepening personalized interaction between service providers and customers (Huotari et al., 2015). Technology is described as the technical quality and online tools that support social interaction, information processing, transaction tracking, specialized software and business management (Chompis et al., 2014). Scholars suggested that service companies who take advantage of technology, specifically the information technology can improve efficiency. Technology can customize services, products, promotions and price to the specific customer, whilst simultaneously reducing service errors and failures (Cummins and Santomero, 2012). Dimensions of technology-based services include information gathering, ease of use, accuracy, network among customers and mass customization (Santos, 2003). In this study, technology was investigated in a different context in the relationship with PSQ and WOM behavior. Consequently, previous studies were revised suggesting the following items included for the technology factor, namely using social sites to provide support and information to customers, creating technology-based facilities to support and solve problems of customers. These systems are then used for client management, quote generation, payment options and status checking.

\section{Premium}

Organization buyers tend to use price as a key factor to assess quality in case of difficulty in making comparison the quality among different providers and evaluating the service offered (Sharma et al., 2009). Organizations may have troubles with price uncertainty and they also try to seek credible information about the price of service products from trustworthy experts, therefore, WOM communication also play an important role in the decision-making process (Kim, 2014). Insurance premium is the price paid by the customers (Thiruvattal et al., 2013). In general insurance services, insurers take responsibility on an amount of compensation - the premium for customers' certain unpredictable and unexpected losses or damages (Ohlsson and Johansson, 2010). This study considered insurance premium as the price that the insured pay to the insurance company for risk compensation and claims settlement in case of unexpected losses or damages. Ohlsson and Johansson (2010) identified different types of premium, namely overall premium, pure premium and earned premium. In a competitive insurance market, each policyholder must execute the fairness of premium by paying an appreciated amount of premium that corresponds to the predictable losses transferred to the insurers. The appropriate premium is the combination of risk estimation, risk characteristics observations and summary of the insured's claim history (David, 2015). From the service marketing perspective in this study, the authors suggested items of premium including competitive premium, discount programs, flexible policies, various premium rates, appropriate policies for premium debt and extra benefits offerings in an insurance package.

\section{Technical skills}

Technical skills have been found to have positive relationship with PSQ. Nasr et al. (2012) asserted that handling service problems properly and solving issues of customers effectively are highly regarded and crucial in customers' perceptions towards service quality. In other words, the proper knowledge and experience, prompt settlement of complaints, effective compensation policy, sympathy and reassurance are all required to perform by service staffs (Lai et al., 2007). WOM behavior were also proved to have effectiveness in case an expert with broad knowledge base or a knowledgeable person rather than a non-expert convey the information (Wangenheim \& Bayón, 2004), implying the specialized knowledge of professional services and technical skills have positive effect on WOM behavior of the satisfied customers.

In the study about customer orientation of service employees, Hennig-Thurau (2004) stated that technical skills is "the knowledge and those technical or motor skills which a service employee must possess in order to fulfil the customer's needs during the personal interaction process". (Darr, 2008) described technical skills as the ability to manipulate things. Technical skills in this study are defined as knowledge and professional skills relevant to general insurance products and services, required procedures of claims settlement and risk compensation that the service staff must possess in order to meet 
the customers' needs. Rentz et al. (2002) identified that there exist six items of technical skills: "knowledge of customers' markets and products; own company's procedures; competitors' products, services and sales policies; product line, including product features and benefits; customers' operations; employee training and margination in supplying products and services that meet the customers' needs". Combined by Rentz et al. (2002) recommendations, this study adapted the items of technical skills factor to be the knowledge of product line, customers' operations, insurance policies and procedures as well as the knowledge of competitors' products, services and insurance-related policies.

\section{Reliability}

As created the SERVQUAL model, Parasuraman et al. (1988) identified reliability as one of the five main dimensions of service quality measurement. Especially in B2B context, customers' evaluation about the company is not only influenced by how the company meet their needs but also by the degree of responsiveness and how it is easy to do business with the company (Kumar \& Grisaffe, 2004). Chaniotakis and Lymperopoulos (2009) also proved that reliability is an antecedent of positive WOM behavior. Reliability is the service provider's ability to perform the promised service in a timely and reliable manner (Gunawardane, 2011). Simons (2004) further developed the notion of Parasuraman et al. (2002) of reliability stating it means performing or offering service accurately, consistently and dependably as promised to the customers. Galetzka et al. (2006) defined service reliability is an appraisal as to what extent the service is correctly performed; thus, high service reliability may be considered as the best practice of service performance. For insurance services, reliability is a key factor because insurance is a business based on customer's trust that a provider will deliver as promised (Chinomona et al., 2014). This study generalized the definition of reliability to mean performing and delivering insurance service accurately, consistently and dependably as promised to the customers. The dimensions of reliability have been explored in the literature with different service fields and various research aspects. Particularly, reliability can be demonstrated by dependability, non-error records, willingness and ability to solve the problems of the customers (Gilbert, 2000); the provision of service expeditiously, accurate and verified information honoring commitments and providing products or services (Kang et al., 2002). The trustworthiness of the service provider in delivering service promptly and consistently, as well as the honest and believable employees are important elements of reliability (Høst \& Knie-Andersen, 2004). This study adapted items of reliability suggested by Parasuraman et al. $(1985,1988)$ in order to make them adaptable to the professional B2B context. Particularly, reliability items consisted of sufficient capital and reinsurance for risk coverage, clear terms and conditions in insurance policies, appropriate risk management solutions, simple and effective claims procedures as well as quick loss assessment and claim payment.

\section{Reputation}

Reputation is considered as the seal of service provider's competence and service quality mainly due to the typical characteristics of service, for example, the difficulty for customers in evaluating the quality and performance prior to consumption or even after consumption. Hence, customers tend to rely mostly on reputation to evaluate the service businesses and service quality, particularly non-separable services (Ekeledo \& Sivakumar, 2004). Positive relationship between reputation and WOM behavior has been proved in previous research. Customers are likely to spread corporate reputation, good experiences about products and services to new customers through WOM communication (Fombrun et al., 2004). Bendixen et al. (2004) confirmed by their research that B2B purchaser are willing to pay high premium and give recommendation to others about their favorite service provider. Barnett et al., (2006) divided reputation into three categories: a state of awareness, an assessment and an asset. In this study, definition of reputation belongs to the clusters of awareness and asset because reputation was considered a component of customer perceptions toward the quality of general insurance service, as well as RBV theory was the groundwork of the research model. According to these clusters, reputation can be defined as the key characteristics and attributes performed in the competition process, that brings the outcome of strengthening the status in the market. Essentially, reputation is comprehensively comprised from intangible resources and assets, history of business operations, product and service quality. Shamma (2012) claimed that corporate reputation is a comprehensive concept involving six items: Corporate associations, corporate branding, corporate communication, corporate identity, corporate image and corporate personality. In insurance services, Thiruvattal et al. (2013) suggested six items belong to positive reputation, namely "prompt settlement of claims, keeping promises, reputation of the branch, efficiency in assessing damages, professional management and efficiency in handling changes in risk conditions". After reviewing previous studies, this study measured reputation by experience in area, expertise in area, staff capabilities, range of services, creativity in problem solving as well as the abilities to meet deadlines and meet client needs as the dimensions of reputation factor of a general insurance service provider in professional B2B context.

\section{Risk coverage}

Dimensions of insurance risk coverage such as the terms and conditions in insurance policies, policy document and potential compensation, have been proved to be the fundamental determinants of insurance service quality (Thiruvattal et al., 2013). However, primary data were used in this research to study the relationship between risk coverage and WOM behavior due to a little proven validation about this relationship in previous studies. Thiruvattal et al. (2013) defined risk coverage as an act of protection for the firms towards losses or damages by managing and preventing potential risks. For example, buying insurance products or packages to cover the risks. This definition is also suitable in the current context. Guillén et al. (2014) 
suggested as the "variability of intrinsic insurance value due to business volumes and margins fluctuations triggered by the competitive environment". Cummins and Doherty (2006) suggested the following items relevant in a discussion of risk coverage: capacity, skills, risk appetite, breadth of coverage, financial strength, the risk management offerings, the reputation for claims settlement, as well as the ability to advise the customers on problem-solving and choosing appropriate product. In order to be suitable with the context in Vietnam, risk coverage dimensions include tailor-made coverage, simple and complete procedures for settling claims, comprehensive coverage and wide network of subsidiaries for guarantees.

- H1: Interpersonal skills, technology, premium, technical skills, reliability, reputation and risk coverage positively affect organization's perceived service quality.

- H2: Interpersonal skills, technology, premium, technical skills, reliability, reputation, risk coverage and organization's perceived service quality positively affect organization's word-of-mouth.

- H3: The effect of interpersonal skills, technology, premium, technical skills, reliability, reputation and risk coverage on organization's word-of-mouth is mediated by its perceived service quality.

\section{Methodology}

\subsection{Methodology}

This study implemented quantitative and qualitative approaches to study about the organization's perceived service quality and word-of-mouth towards general insurance services in Vietnam. Statistical, mathematical and computational techniques were applied to test the hypotheses and relationships between independent and dependent variables with the aims to provide objective research results and scope for feasible recommendations. In-depth interviews, focus group interviews and expert interviews were applied for qualitative method. In-depth interviews were conducted chronologically with semi-structured and unstructured questions in order to identify all factors affecting the OPSQ and WOM in factual circumstances. The respondents are those who buy general insurance products of well-known providers. Focus group interviews were conducted with the representatives of general insurance agents, sales and claims managers from different general insurance providers that have large market share for further research about the factors affecting the OPSQ and WOM behavior. Expert interviews helped review the management scale, model variables and survey questionnaires to check whether they are suitable for B2B professional general insurance services in Vietnam.

\subsection{Measurements}

Items of each factor in the survey questionnaires were built on the basis of reviewing the literature and revising to the research context. Particularly, OPSQ was adapted from the customer-based performance measure (Parasuraman et al., 1985, 1988, 1991) because it has long been widely used in various contexts of the service industry and the adoption of SERVQUAL model facilitates comparison to other studies (Yavas et al., 2004). On the other hand, ORWOM was operationalized based on the investigation of service quality as antecedent (Harrison-Walker, 2001). For independent variables, the authors reviewed and revised the measurement scales of previous research to conduct the construction that would be suitable for the context of this research. Seven-point Likert scale were used to design the survey questionnaires due to more options which reflect the objective reality of the respondents and better performed results. The survey questionnaire included two parts: demographic information and factors assessment. The demographic information using a nominal scale that asked about the information relevant to the background characteristics of organization customers and about the type of business structure of insurance company. Meanwhile, other questions about the research factors were measured using an ordinal scale. After identifying dimensions of each independent variable, respondents were asked to rate their level of agree on those dimensions from $1=$ "strongly disagree", 2 = "disagree", 3 = "somewhat disagree", 4 = "neutral" to $5=$ "somewhat agree", $6=$ "agree" and $7=$ "strongly agree" (Brown, 2015).

\subsection{Sample and Data collection}

As having literature support and expert support for conceptuality of variables and relationships between independent and dependent variables, structured survey questionnaires were designed and distributed to organization customers of general insurance companies throughout Vietnam from Hanoi, Hue, Da Nang to Binh Thuan and Ho Chi Minh City by both direct approach (convenience sampling) and indirect approach (snowball sampling). For direct approach, the authors together with the sales and claims managers of general insurance companies conducted appointments to meet the organization customers who had expired insurance policies and willingness to sign renewal policies. After signing the insurance policies, the survey questionnaires were distributed to the organization customers and the responses were collected immediately afterwards. In order to expand the sample size, the survey questionnaires were also given to the sales and claims managers of insurance companies to help collect responses from their organization customers. It took in total 10 months to collect results and reach the target sample size. 


\subsection{Factor Analysis and Reliability}

The exploratory factor analysis procedure was applied twice; once for the dependent variable, including 11 items, and once for the group of independent variables, including 39 items. Seven independent variables were created after applying the Varimax rotation, made up $64.677 \%$ of the total variance, and the Eigenvalues were greater than 1. The Kaiser-Meyer-Olkin Measure of Sampling Adequacy (KMO) index was .932 higher than .5, which indicated that principal component analysis can be applied to the group of independent variables (Pallant, 2005). The significance of Bartlett's test was at .000 smaller than .05 , indicating the suitability of data for factor analysis and the sufficient correlation between variables for further test. All factors also had high value of Cronbach's Alpha (from .801 to .918), illustrating the high reliability of the measurement scale for assessing the independent variables.

Table 1

Summary of Independent Variables

\begin{tabular}{lcc}
\hline \multicolumn{1}{c}{ Factors } & Number of Items & Cronbach's Alpha (N=547) \\
\hline Interpersonal Skills (INS) & 6 & .918 \\
Technology (TLGY) & 7 & .885 \\
Premium (PREM) & 7 & .872 \\
Technical Skills (TES) & 6 & .891 \\
Reliability (RELT) & 6 & .811 \\
Reputation (REPU) & 4 & .801 \\
Risk Coverage (RISCO) & 3 & .864 \\
\hline
\end{tabular}

For the dependent variables, the Eigenvalues were all greater than 1 and total variance explained was $64.390 \%$. KMO index was .885 greater than .5 and the significance of Bartlett's test was .000 smaller than .05 implying the appropriateness for factor analysis of the data of two dependent variables. High factor loadings that were greater than .5 indicating the high correlation between each item and the corresponding extracted component and all items in the extracted components were appropriate. Similarly, the high value of Cronbach's Alpha also illustrating good reliability of the measurement scale for assessing the dependent variables.

Table 2

Summary of Dependent Variables

\begin{tabular}{lcc}
\multicolumn{1}{c}{ Factors } & Number of Items & $\begin{array}{c}\text { Cronbach's Alpha } \\
(\mathrm{N}=547)\end{array}$ \\
\hline Organization's Perceived Service Quality (OPSQ) & 5 & .872 \\
Organization's Word-of-mouth (ORWOM) & 6 & .909 \\
\hline
\end{tabular}

\section{Research findings}

\subsection{Characteristics of Respondents}

Table 3

Demographic of Respondents

\begin{tabular}{|c|c|c|c|}
\hline & & Frequency & Valid Percentage \\
\hline \multirow{6}{*}{ Business Field } & Production & 126 & $23.00 \%$ \\
\hline & Construction & 41 & $7.50 \%$ \\
\hline & Service & 254 & $46.40 \%$ \\
\hline & Administration & 45 & $8.20 \%$ \\
\hline & Trading & 183 & $33.50 \%$ \\
\hline & Total & 547 & $100.00 \%$ \\
\hline \multirow{4}{*}{ Number of Employees } & Less than 50 employees & 186 & $34.00 \%$ \\
\hline & $50-300$ employees & 213 & $38.90 \%$ \\
\hline & Over 300 employees & 148 & $27.10 \%$ \\
\hline & Total & 547 & $100.00 \%$ \\
\hline \multirow{4}{*}{ Insurance Company } & $100 \%$ Foreign Investment & 169 & $30.90 \%$ \\
\hline & Domestic Investment & 241 & $44.10 \%$ \\
\hline & Joint Venture & 137 & $25.00 \%$ \\
\hline & Total & 547 & $100.00 \%$ \\
\hline
\end{tabular}

Table 3 compared the shares of five major items in business field of the organization customers responding to the questionnaire. Although data include the organizations that have multifunctional business, it can be seen that nearly a half of respondents $(46.40 \%)$ were from service business field, followed by trading (33.50\%) and production $(23.00 \%)$ business fields.

On the other hand, only $8.20 \%$ and $7.50 \%$ of respondents orderly belonged to administration and construction business fields. Different business fields have different consumption behaviors and require specialized insurance package. Therefore, it should be noted that implementing appropriate strategies to approach target customers and customizing suitable products and services can promote WOM communication within B2B community (Jalilvand et al., 2017). 
There are $38.90 \%$ of respondents had from 50 to 300 employees, $34.00 \%$ of respondents had less than 50 employees and the rest $27.10 \%$ of respondents had over 300 employees. The data illustrate that medium enterprises account the largest proportion, followed by small enterprises with slightly smaller proportion while large enterprises account for the smallest share, indicating the medium and small scale of almost enterprises in Vietnam. It can be concluded from the Table 3 that general insurance providers should diversify and design a variety of products and services to meet the specific demands and requirements of these different groups of organization customers. Organization customers mostly preferred to purchase products from domestic investment general insurance companies $(44.10 \%)$. The number of customers buying insurance products from the other two types of insurance companies also accounted for a significant proportion, respectively $30.90 \%$ for $100 \%$ foreign investment companies and $25.00 \%$ for joint ventures. Obviously, the fierce and aggressive competition in insurance market together with the high probability of switching to use services offered by competitors raise the issue to general insurance providers to retain current customers and attract more potential customers.

\subsection{Correlations between Variables}

With the aim to test the groups of hypotheses, multiple regression analysis was carried out twice between independent variables and OPSQ (H1), ORWOM (H2) as well as path analysis and bootstrapping method were also applied to examine the indirect and total effect on ORWOM (H3).

Table 4

Pearson Correlations between Independent Variables and OPSQ

\begin{tabular}{|c|c|c|c|c|c|c|c|c|}
\hline & OPSQ & 1 & 2 & 3 & 4 & 5 & 6 & 7 \\
\hline 1. INS & .492 & 1.000 & & & & & & \\
\hline 2. TLGY & .372 & .408 & 1.000 & & & & & \\
\hline 3. PREM & .516 & .414 & .490 & 1.000 & & & & \\
\hline 4. TES & .539 & .605 & .400 & .566 & 1.000 & & & \\
\hline 5. RELT & .455 & .397 & .367 & .530 & .556 & 1.000 & & \\
\hline 6. REPU & .571 & .472 & .484 & .530 & .580 & .549 & 1.000 & \\
\hline 7. RISCO & .513 & .420 & .483 & .595 & .575 & .612 & .569 & 1.000 \\
\hline $\begin{array}{c}\text { Mean } \\
\end{array}$ & 4.801 & 5.142 & 4.889 & 5.014 & 5.109 & 5.275 & 4.930 & 5.313 \\
\hline SD & 1.162 & 1.167 & 1.084 & .989 & .997 & .830 & 1.038 & 1.036 \\
\hline
\end{tabular}

Note: All correlations are significant at the .05 level $(\mathrm{p}=.000)$

According to the results from Pearson's correlation test, all independent variables were positively correlated with the mediator OPSQ and with each other. To be more specific, RISCO and RELT together with TES and INS have high correlations with $\mathrm{r}=.612, \mathrm{p}<.05$ and $\mathrm{r}=.605, \mathrm{p}<.05$ respectively, implying the closed relationships between two pairs of factors risk coverage reliability and technical skills - interpersonal skills. Conversely, the low effects between RELT and two variables INS and TLGY ( $r=.397, p<.05$ and $r=.367, p<.05$ respectively) illustrates the slight relationship between two pairs of independent variables reliability - interpersonal skills and reliability - technology. The other independent variables were shown to have moderate relationships with each other.

Moreover, REPU were the independent factor that have the highest effect on the mediator OPSQ $(r=.571$, $\mathrm{p}<.05)$, which meant a more reputable company would be able to impact more on organization's perceived service quality. On the other hand, independent factor of technology was shown to have the least impact on organization's perceived service quality with the lowest correlation between TLGY and OPSQ $(\mathrm{r}=.372, \mathrm{p}<.05)$. The other five independent variables were shown to have moderate correlations with the mediation variable OPSQ (ranging from $\mathrm{r}=.455$ to $\mathrm{r}=.539$ ), illustrating the predictable influences of these explanatory factors on organization's perceived service quality.

Table 5

Coefficients between Independent Variables and OPSQ

\begin{tabular}{|c|c|c|c|}
\hline Variables & Unstandardized Coefficients (B) & $\mathbf{t}$ & Sig. \\
\hline & .010 & .038 & .970 \\
\hline INS & .181 & 4.366 & .000 \\
\hline TLGY & -.023 & -.529 & .597 \\
\hline PREM & .195 & 3.723 & .000 \\
\hline TES & .125 & 2.216 & .027 \\
\hline RELT & .034 & .547 & .585 \\
\hline REPU & .294 & 5.868 & .000 \\
\hline RISCO & .137 & 2.598 & .010 \\
\hline $\begin{array}{ll}\text { - } & \text { Dependent Variable: } \text { OPSQ } \\
\text { - } & \text { Predictors: } I N S, T L G Y, P R L \\
\text { - } & \text { ANOVA: } F(7,539)=62.71 \\
\text { Model summary: } R^{2}=.449\end{array}$ & $\begin{array}{l}L T, R E P U, R I S C O \\
0, p<.05\end{array}$ & & \\
\hline
\end{tabular}

It can be seen from Table 5 that five independent variables INS, PREM, TES, REPU and RISCO significantly affected OPSQ with coefficients of $\mathrm{B}=.181(\mathrm{p}<.05), \mathrm{B}=.195(\mathrm{p}<.05), \mathrm{B}=.125(\mathrm{p}<.05), \mathrm{B}=.294(\mathrm{p}<.05)$ and $\mathrm{B}=.137(\mathrm{p}<.05)$ respectively. 
Consequently, organization's perceptions towards service quality would be increase when interpersonal skills, premium, technical skills, reputation and risk coverage factors of general insurance service providers were positive.

$$
\text { OPSQ }=.010+.181 \times \text { INS }+.195 \times \text { PREM }+.125 \times \text { TES }+.294 * \text { REPU }+.137 \times \text { RISCO }
$$

In accordance with the ANOVA, the model was proven to be significant at $95 \%$ confidence level due to Sig. $=.000$ or $p<$ .05. From the model summary, $\mathrm{F}$ value was 62.710 and $\mathrm{R}$ square was .449 , implying that five independent factors (INS, PREM, TES, REPU and RISCO) helped explain about $44.9 \%$ of the variance in organization's perceived service quality (OPSQ).

Table 6

$\underline{\text { Pearson Correlations between all variables of the Research Model }}$

\begin{tabular}{|c|c|c|c|c|c|c|c|c|}
\hline & ORWOM & 1 & 2 & 3 & 4 & 5 & 6 & 7 \\
\hline 1. INS & .623 & 1.000 & & & & & & \\
\hline 2. TLGY & .461 & .408 & 1.000 & & & & & \\
\hline 3. PREM & .486 & .414 & .490 & 1.000 & & & & \\
\hline 4. TES & .534 & .605 & .400 & .566 & 1.000 & & & \\
\hline 5. RELT & .489 & .397 & .367 & .530 & .556 & 1.000 & & \\
\hline 6. REPU & .517 & .472 & .484 & .530 & .580 & .549 & 1.000 & \\
\hline 7. RISCO & .577 & .420 & .483 & .595 & .575 & .612 & .569 & 1.000 \\
\hline 8. OPSQ & .543 & .492 & .372 & .516 & .539 & .455 & .571 & .513 \\
\hline Mean & 4.855 & 5.142 & 4.889 & 5.014 & 5.109 & 5.275 & 4.930 & 5.313 \\
\hline SD & 1.151 & 1.167 & 1.084 & .989 & .997 & .830 & 1.038 & 1.036 \\
\hline
\end{tabular}

Note: All correlations are significant at the .05 level $(\mathrm{p}=.000)$

As shown in Table 6, all independent variables were positively correlated with the dependent variable ORWOM, with the mediator OPSQ and with each other. Particularly, INS were proved to have the strongest effect on ORWOM with $\mathrm{r}=.623$, $\mathrm{p}<.05$, indicating that the better interpersonal skills the service staffs have, the more likelihood the organization customer would execute WOM behavior. Among these variables, TLGY had the lowest effect on ORWOM with $\mathrm{r}=.461$, $\mathrm{p}<.05$. It can be found that the correlation coefficients are rather high among the variables, within the range from $\mathrm{r}=.461$ to $\mathrm{r}=.623$ and almost are moderate correlations, which meant the existence of positively direct effects of all independent variables on dependent variable ORWOM. In case of the relationship between the mediator OPSQ and dependent variable ORWOM, there was also a moderate correlation with $\mathrm{r}=.543, \mathrm{p}<.05$, implying a positive relationship between how the organization's perceived service quality and the likelihood they tell good things or recommend others to use the products and services of a general insurance service provider.

Table 7

Coefficients between Independent Variables, OPSQ and ORWOM

\begin{tabular}{|c|c|c|c|}
\hline Variables & Unstandardized Coefficients (B) & $t$ & Sig. \\
\hline & -.365 & -1.537 & .125 \\
\hline INS & .361 & 9.497 & .000 \\
\hline TLGY & .100 & 2.615 & .009 \\
\hline PREM & .028 & .581 & .561 \\
\hline TES & -.017 & -.327 & .744 \\
\hline RELT & .108 & 1.936 & .053 \\
\hline REPU & .042 & .898 & .369 \\
\hline RISCO & .250 & 5.219 & .000 \\
\hline OPSQ & .149 & 3.837 & .000 \\
\hline
\end{tabular}

- Dependent Variable: ORWOM

- Predictors: INS, TLGY, PREM, TES, RELT, REPU, RISCO, OPSQ

- $\quad$ ANOVA: $F(8,538)=80.297$, Sig. $=.000, p<.05$

- Model summary: $R^{2}=.544$

Regarding to the Table 7, four explanatory factors INS, TLGY, RISCO and OPSQ were shown to have significantly positive effect on ORWOM with $\mathrm{B}=.361(\mathrm{p}<.05), \mathrm{B}=.100(\mathrm{p}<.05), \mathrm{B}=.250(\mathrm{p}<.05)$ and $\mathrm{B}=.149(\mathrm{p}<.05)$ respectively. This means that every 1-standard deviation increase in interpersonal skills, technology, risk coverage and organization's perceived service quality would lead to the increase in the level of organization's word-of-mouth by $.361, .100, .250$ and .149 units, in the order. INS had the highest direct effect on ORWOM; RISCO ranked the second and followed by OPSQ, indicating the employee's interpersonal skills, the firm's ability to cover risk as well as the organization customer's perceptions towards the general insurance service providers would be the three most influential factors affecting positively and directly the possibility of WOM communication or behavior.

$$
\text { ORWOM }=-.365+.361 \times \text { INS }+.100 \times \mathrm{TLGY}+.250 \times \mathrm{RISCO}+.149 \times \mathrm{OPSQ}
$$

The ANOVA showed that the model was significant at $95 \%$ confidence level with Sig. $=.000$ or $\mathrm{p}<.05$. Besides, the model summary, F value was 80.297 and R square was .544, indicating that three independent factors (INS, TLGY, RISCO) together with the mediation factor (OPSQ) helped explain about $54.4 \%$ of the variance in organization's word-of-mouth (ORWOM). 
Moreover, all coefficients in the total effects model were significant at 95\% confidence level and the result of hypotheses testing were shown in the path diagram below.

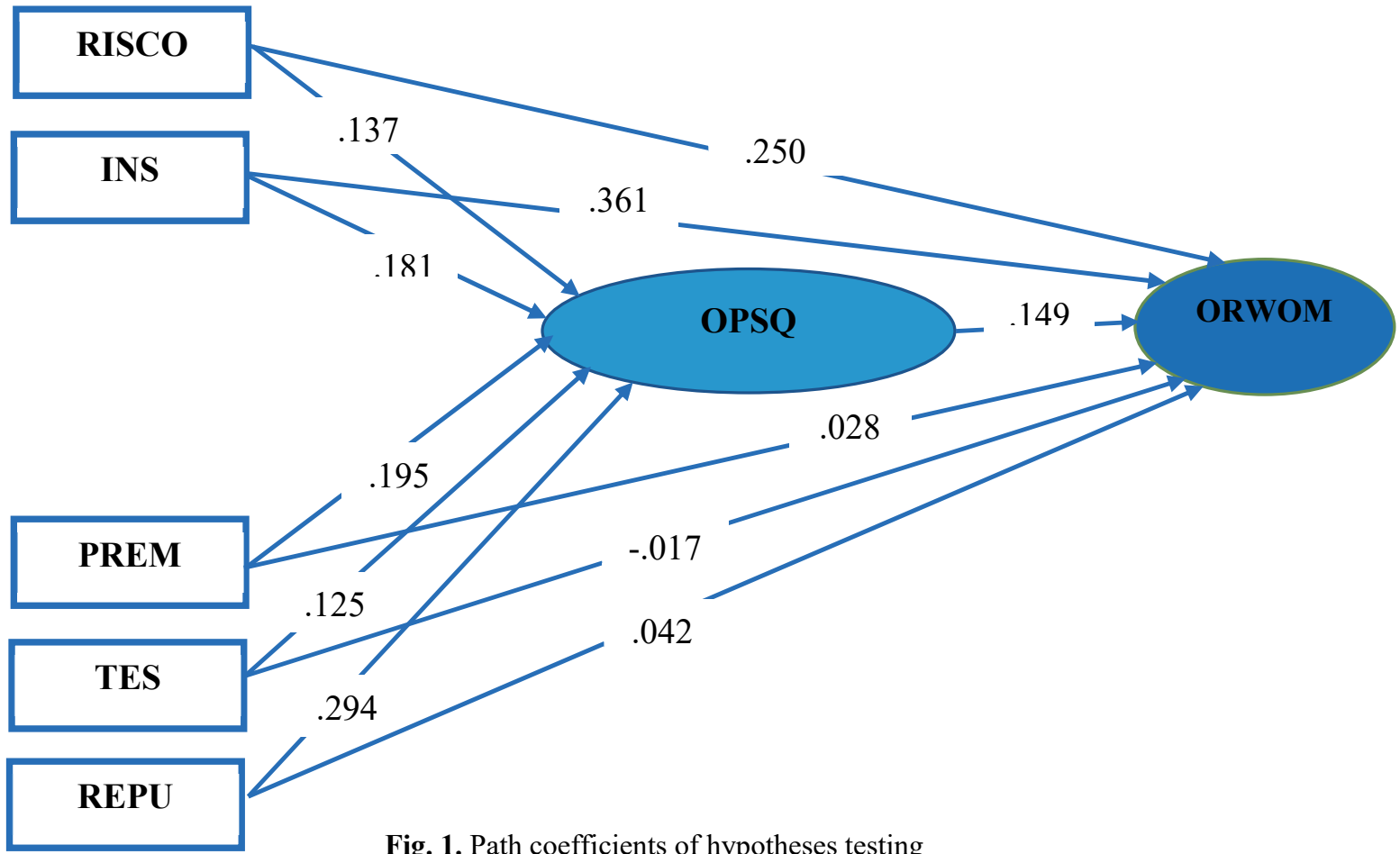

Fig. 1. Path coefficients of hypotheses testing

Note: All coefficients in the model are significant at 95\% confidence level

To further the analysis, a bootstrapping method was applied in order to confirm the significance of the indirect effects between those explanatory variables and ORWOM mediated by OPSQ. Particularly, Preacher \& Hayes (2008) claimed that if the zero (0) falls between the lower level confidential interval (LLCI) and upper level confidential interval (ULCI), there is not significantly indirect effect or no existence of the indirect effect; otherwise, the indirect effect is proved.

Table 8

Direct, Indirect and Total Causal Effect on ORWOM

\begin{tabular}{|c|c|c|c|c|c|}
\hline \multirow{2}{*}{ Variables } & \multicolumn{3}{|c|}{ Causal Effects } & \multirow{2}{*}{ LLCI } & \multirow{2}{*}{ ULCI } \\
\hline & Direct & Indirect & Total & & \\
\hline 1. INS & .361 & .027 & .388 & .0125 & .0439 \\
\hline 2. PREM & .028 & .029 & .057 & .0124 & .0484 \\
\hline 3. TES & -.017 & .019 & .002 & .0043 & .0365 \\
\hline 4. REPU & .042 & .044 & .086 & .0228 & .0682 \\
\hline 5. RISCO & .250 & .020 & .270 & .0063 & .0380 \\
\hline 6. OPSQ & .149 & --- & .149 & & \\
\hline Total & .813 & .139 & .952 & & \\
\hline
\end{tabular}

It can be seen from the above table that all values in LLCI and ULCI columns are positive and there is no existence of 0 (zero) between them. Thus, the indirect effects of INS, PREM, TES, REPU and RISCO on ORWOM mediated by OPSQ were claimed at $95 \%$ confidence interval. Specifically, INS was shown to have the strongest effect on ORWOM with B $=.388$, which meant the moderate relationship in accordance with the rules of strength of path coefficients (De Vaus, 2002). Furthermore, the value of total effect of the research model was .952 and the value of indirect effect was .139, accounting for $14.6 \%$.

\section{Discussion, recommendation, and limitation}

\subsection{Discussion of findings}

The research findings were compared and contrasted with the results of previous studies to identify the similarities and differences; thereby confirming the consensus opinion, whilst pointing out the discrepancies and reasons in a particular research context or specific situation, whilst simultaneously presenting new conceptual research findings. In spite of the positive rela- 
tionships between explanatory variables and dependent variables, each factor was found to have had different levels of influence. Results of the first multiple regression showed that higher levels of interpersonal skills, premium, technical skills, reputation and risk coverage generated better OPSQ. In particular, with the highest value of B (B = .294), "reputation" was proved to have the strongest positivity impact on OPSQ. The "premium" was the second influential factor with B $=.195$, "interpersonal skills" were the third influential factor with $\mathrm{B}=.181$ and "risk coverage" was the fourth influential factor with $\mathrm{B}=.137$, implying the moderate influences on OPSQ. With the smallest value of $\mathrm{B}(\mathrm{B}=.125)$, "technical skills" was proved to have least influence on how the OPSQ. In summary, all five independent variables had moderate direct effects on OPSQ according to the coefficient values (De Vaus, 2002).

The results of the second multiple regression performed the significant effect of OPSQ on ORWOM with B $=.149$, Sig $=$ .000 , implying the higher level of perceptions of service quality the organization customers have, the more likely they spread WOM information. Moreover, coefficients between "interpersonal skills", "technology, "risk coverage" and ORWOM was B $=.361, \mathrm{Sig}=.000, \mathrm{~B}=.100, \mathrm{Sig}=.009$ and $\mathrm{B}=.250, \mathrm{Sig}=.000$. Therefore, it is sufficient to conclude that the increase in degree of interpersonal skills, technology and risk coverage would lead to the higher possibility of WOM behaviors of organization customers. The application of path analysis and bootstrapping method showed that the effects of INS, PREM, TES, REPU and RISCO on ORWOM through OPSQ were (.027), (.029), (.019), (.044) and (.020) respectively, which made up the total causal effects on ORWOM of (.388), (.057), (.002), (.086) and (.270) respectively. In other words, interpersonal skills, premium, technical skills, reputation and risk coverage factors have indirect relationships with ORWOM with the mediation role of OPSQ.

The findings concluded that perceived quality plays an important role in influencing organization customers in a B2B context due the direct effect on their behavioral outcomes and mediation role for the indirect effects on behavioral outcomes (Aaker et al., 2008). Strong influence of risk coverage factor on ORWOM through OPSQ in this study suggested increased ability to reduce perceived risk, which leads to higher customer perception towards service quality and accordingly, the wider spread of WOM communication (Wangenheim, 2005). The effect of reputation on ORWOM mediated by OPSQ in this research is also supported by Hutton (1997). He found that organization customers who have high perceptions toward service quality are willing to relay positive information about corporate reputation, making a service referral. Furthermore, the finding of the positively direct relationship between technology and WOM communication was also consistent with the previous studies about how computer mediated communications and interactions (e.g. Walther, 1996, 2007, 2011) and technology-based tools was proved to create tremendous changes in spreading WOM communication (Berger, 2014).

After comparing and contrasting the findings of this research with those of the previous studies, in addition to the confirmation about the indirect effects of reputation and risk coverage on ORWOM through mediation OPSQ, the three other relationships were explored by the combination of practical research and primary data analysis. The target of this exploration into the indirect effects of interpersonal skills, premium and technical skills on ORWOM through OPSQ introduced new research aspects in a particularly unique context of professional B2B general insurance context in Vietnam, which contributed largely to the service marketing and insurance service literature.

\subsection{Recommendations for B2B general insurance industry}

Based on the suggestions of scholars, practitioners, marketers and those of insurance experts in Vietnam, the researchers proposed solutions in specific for each element in order to be applicable to the B2B professional general insurance context in Vietnam. Chakrabarty et al. (2008) suggested service employees practice interpersonal skills by informing customers regularly about situation and status, providing them with sufficient information, explaining pros and cons, help the customers make critical decisions, whilst expressing good attitudes to the customers. Service providers train employees in social skills and build a team of like-minded professionals to enhance interactions within B2B community (Bruhn et al., 2014).

It is advisable for professional firms to perform beyond the expectations of customers by designing products and services that meet their significant demands and approach the customers' insights (Lang \& Lawson, 2013). General insurance companies should discuss risks openly and thoroughly with customers before completing transactions, listening to customers to identify coverage needs and manage risk. Such process should provide suitable risk-reducing incentives and compensation procedures ought to provide a framework for fair treatment of claims in order to gain profitability and sales growth in long term. For insurance premiums, customers naturally are concerned about the price of service products and whether the product itself meets their needs, therefore service providers must focus attention to thoroughly explain all pertinent information, before instigating a transaction for purchase (Al-Hawari et al., 2005). Hence, service providers should establish different rates, offer competitive premium, create flexible policies for the customers to choose. Customers also often take the financial statements of insurance companies into consideration to choose the service provider (Cummins and Doherty, 2006) so that building financial strengths and premium rates charged for given risk coverage is vital. Factors affecting customers' perceptions towards corporate reputation have been comprehensively studied including "information from the organization, brand activities in terms of customer image, community image, investor image, employee image, rumor, journalistic insights, investment analysis and audit data" and "individuals' experiences with the company, company's self-presentations and word-of-mouth" (Shamma, 2012). These components outline the framework for insurance companies to develop and implement appropriate 
marketing campaigns to build reputation in every aspect. Moreover, consumers has been proven to be more impressed by socially responsible companies (Hsu, 2012). Therefore, persuasive advertising effects relating to CSR initiatives should be highlighted and distinguished from informative advertising effects for customers' recognition and awareness.

Finally, Boress and Cummings (2002) specifically noted that technical competence and excellence are the indispensable factor that all organization customers expect the professional service providers to possess.. Thus, the service employees should be trained to explain the professional and technical details in a comprehensible and meaningful way. Almost all products and services of professional services require highly specialized knowledge outputs (Greenwood et al., 2005). The high competitiveness of professional insurance services in era of high technology and knowledge-based economy necessitates that the service staff should be very well equipped with technical skills, products, services and operational process to ensure success.

\subsection{Limitations and future research}

Firstly, data were collected only in major cities and provinces in Vietnam. Therefore, the sample is not representative of all organization customers of general insurance services in Vietnam. The sample size is sufficiently robust but it does not represent data collected from all firms in Vietnam.

Secondly, the measurement scale adopted by this study was applicable to the B2B context and general insurance service sector, necessarily be studied in the scope of B2C context and life insurance service to examine its validity and feasibility. In addition, there would be various mediation variables intervening in the relationships between explanatory variables and WOM such that it is necessary to conduct further exploratory research to have revised measurement scales matching with different research contexts.

Finally, it is necessary to consider some factors of the research model due to the differences between research findings of previous scholars. For example, the direct effect of technology on PSQ have been examined and confirmed in numerous studies (Wolfinbarger and Gilly, 2001; Zeithaml et al., 2002 and Parasuraman et al., 2005) and suggested to have indirect with organization's word-of-mouth as well (Taylor et al., 2002). However, they found no significant correlation between this variable and organization's perceived service quality or organization's word-of-mouth. Similarly, the items of reliability factor in this study were built based on the SERVQUAL measurement scale of Parasuraman et al. (1985, 1988), which implied the significantly positive relationship between reliability and PSQ. However, reliability was found to have no significant relationship with organization's perceived service quality or indirect effect on organization's word-of-mouth, suggestive rebuttal to the SERVQUAL model in the B2B context (Sharma and Mehta, 2004). To sum up, further studies about the effects of these two factors on organization's perceived service quality and organization's word-of-mouth are also required in order to obtain the confirmation in $\mathrm{B} 2 \mathrm{~B}$ professional general insurance services.

\section{Conclusion}

In conclusion, the research objectives have been proved to answer the research questions. The study had both theoretical and practical contributions to the fields of service marketing and general insurance service industry. The implications generating from this study promoted a new direction for more in-depth research on WOM intention and behavior in B2B context as well as supported for further studies about service marketing in professional insurance services in Vietnam.

The results of this study would offer some direction to general insurance providers that would like to retain regular customers and implement WOM communication as a service marketing strategy to attract potential customers on the basis of positive perceptions towards the service quality.

This study claimed the direct effects of interpersonal skills, premium, technical skills, reputation and risk coverage on organization customer perceived service quality and their WOM behavior as well as the indirect effects of those variables on organization customer word-of-mouth through their perceptions towards service quality. Among these variables, interpersonal skills and risk coverage were the two most influential factors with the total effect of $\mathrm{B}=.388(\mathrm{p}<.05)$ and $\mathrm{B}=.270(\mathrm{p}<.05)$ respectively. The research findings were also compared to other studies and the similarities and differences were also discussed to demonstrate how this research contributes to the knowledge of service marketing management and general insurance services literature.

Last but not least, based on the empirical research findings, the study provided suggestions and directions to enhance organization's word-of-mouth by promoting the strengths and minimizing the weaknesses in terms of employees' interpersonal skills and technical skills, insurance premium and risk coverage as well as corporate reputation.

\section{References}

Aaker, D. A., Kumar, V., \& Day, G. S. (2008). Marketing research. John Wiley \& Sons.

Alexandris, K., Dimitriadis, N., \& Markata, D. (2002). Can perceptions of service quality predict behavioral intentions? An exploratory study in the hotel sector in Greece. Managing Service Quality: An International Journal, 12(4), $224-231$. 
Al-Hawari, M., Hartley, N., \& Ward, T. (2005). Measuring Banks' Automated Service Quality: A Confirmatory Factor Analysis Approach. Marketing Bulletin, 16.

Barnett, M. L., Jermier, J. M., \& Lafferty, B. A. (2006). Corporate reputation: The definitional landscape. Corporate Reputation Review, 9(1), 26-38.

Bendixen, M., Bukasa, K. A., \& Abratt, R. (2004). Brand equity in the business-to-business market. Industrial Marketing Management, 33(5), 371-380.

Berger, J. (2014). Word of mouth and interpersonal communication: A review and directions for future research. Journal of Consumer Psychology, 24(4), 586-607.

Boress, A. S., \& Cummings, M. G. (2002). Mastering the Art of Marketing Professional Services: A Step-by-step Best Practices Guide. American Institute of Certified Public Accountants, Incorporated.

Brady, M. K., \& Cronin, J. J. (2001). Some New Thoughts on Conceptualizing Perceived Service Quality: A Hierarchical Approach. Journal of Marketing, 65(3), 34-49.

Brown, T. A. (2015). Confirmatory factor analysis for applied research. Guilford Publications.

Bruhn, M., Schnebelen, S., \& Schäfer, D. (2014). Antecedents and consequences of the quality of e-customer-to-customer interactions in B2B brand communities. Industrial Marketing Management, 43(1), 164-176.

Chakrabarty, S., Whitten, D., \& Green, K. (2008). Understanding service quality and relationship quality in IS outsourcing: Client orientation \& promotion, project management effectiveness, and the task-technology-structure fit. Journal of Computer Information Systems, 48(2), 1-15.

Chaniotakis, I. E., \& Lymperopoulos, C. (2009). Service quality effect on satisfaction and word of mouth in the health care industry. Managing Service Quality: An International Journal, 19(2), 229-242.

Chawla, S., \& Sharma, P. (2017). An assessment of service quality among general insurance policyholders in Punjab: An empirical study. IUP Journal of Management Research, 16(1), 47.

Chinomona, R., Masinge, G., \& Sandada, M. (2014). The influence of e-service quality on customer perceived value, customer satisfaction and loyalty in south africa. Mediterranean Journal of Social Sciences, 5(9), 331.

Chompis, E., Bons, R. W. H., van den Hooff, B., Feldberg, F., \& Horn, H. (2014). Satisfaction with virtual communities in B2B financial services: Social dynamics, content and technology. Electronic Markets, 24(3), 165-177.

Clemes, M., Shu, X., \& Gan, C. (2014). Mobile communications: A comprehensive hierarchical modelling approach. Asia Pacific Journal of Marketing and Logistics, 26(1), 114-146.

Cronin, J. J., Brady, M. K., \& Hult, G. T. M. (2000). Assessing the effects of quality, value, and customer satisfaction on consumer behavioral intentions in service environments. Journal of Retailing, 76(2), 193-218.

Cummins, D., \& Santomero, A. (2012). Changes in the life insurance industry: Efficiency, technology and risk management (Vol. 11). Springer Science \& Business Media.

Cummins, J. D., \& Doherty, N. A. (2006). The economics of insurance intermediaries. Journal of Risk and Insurance, 73(3), 359-396.

Darr, A. (2008). The Rise of the Techno-Service Sector: The Growing Inter-Dependency of Social and Technical Skills in the Work of ERP Implementers. 2008(1), 8-30.

David, M. (2015). A review of theoretical concepts and empirical literature of non-life insurance pricing. Procedia Economics and Finance, 20, 157-162.

Davis, A., \& Khazanchi, D. (2008). An Empirical Study of Online Word of Mouth as a Predictor for Multi-product Category e-Commerce Sales. Electronic Markets, 18(2), 130-141.

De Vaus, D. (2002). Analyzing social science data: 50 key problems in data analysis. Sage Publications.

Donio', J., Massari, P., \& Passiante, G. (2006). Customer satisfaction and loyalty in a digital environment: An empirical test. Journal of Consumer Marketing, 23(7), 445-457.

Ekeledo, I., \& Sivakumar, K. (2004). International market entry mode strategies of manufacturing firms and service firms: A resource-based perspective. International Marketing Review, 21(1), 68-101.

Fombrun, C. J., Van Riel, C. B., \& Van Riel, C. (2004). Fame \& fortune: How successful companies build winning reputations. FT Press.

Fong, J., \& Burton, S. (2008). A cross-cultural comparison of electronic word-of-mouth and country-of-origin effects. Journal of Business Research, 61(3), 233-242.

Galetzka, M., Verhoeven, J. W., \& Pruyn, A. T. H. (2006). Service validity and service reliability of search, experience and credence services: A scenario study. International Journal of Service Industry Management, 17(3), 271-283.

Gilbert, G. R. (2000). Measuring internal customer satisfaction. Managing Service Quality: An International Journal, 10(3), $178-186$.

Greenwood, R., Li, S. X., Prakash, R., \& Deephouse, D. L. (2005). Reputation, diversification, and organizational explanations of performance in professional service firms. Organization Science, 16(6), 661-673.

Guillén, M., Jarner, S. F., Nielsen, J. P., \& Pérez-Marín, A. M. (2014). Risk-adjusted impact of administrative costs on the distribution of terminal wealth for long-term investment. The Scientific World Journal, 2014.

Gunawardane, G. (2011). Reliability of the internal service encounter. International Journal of Quality \& Reliability Management, 28(9), 1003-1018.

Habibi, F., Hamilton, C. A., Valos, M. J., \& Callaghan, M. (2015). E-marketing orientation and social media implementation in B2B marketing. European Business Review, 27(6), 638-655. 
Haenlein, M., \& Libai, B. (2017). Seeding, Referral, and Recommendation: Creating Profitable Word-of-Mouth Programs. California Management Review, 59(2), 68-91.

Harrison-Walker, L. J. (2001). The measurement of word-of-mouth communication and an investigation of service quality and customer commitment as potential antecedents. Journal of Service Research, 4(1), 60-75.

Hawkins, D. I., \& Mothersbaugh, D. L. (2010). Consumer behavior: Building marketing strategy (11th ed). McGraw-Hill Irwin.

Hébert, A., \& Hauf, P. (2015). Student learning through service learning: Effects on academic development, civic responsibility, interpersonal skills and practical skills. Active Learning in Higher Education, 16(1), 37-49.

Hennig-Thurau, T. (2004). Customer orientation of service employees: Its impact on customer satisfaction, commitment, and retention. International Journal of Service Industry Management, 15(5), 460-478.

Høst, V., \& Knie-Andersen, M. (2004). Modeling customer satisfaction in mortgage credit companies. International Journal of Bank Marketing, 22(1), 26-42.

Hsu, K.-T. (2012). The advertising effects of corporate social responsibility on corporate reputation and brand equity: Evidence from the life insurance industry in Taiwan. Journal of Business Ethics, 109(2), 189-201.

Huotari, L., Ulkuniemi, P., Saraniemi, S., \& Mäläskä, M. (2015). Analysis of content creation in social media by B2B companies. Journal of Business \& Industrial Marketing, 30(6), 761-770.

Hutchinson, J., Lai, F., \& Wang, Y. (2009). Understanding the relationships of quality, value, equity, satisfaction, and behavioral intentions among golf travelers. Tourism Management, 30(2), 298-308.

Hutton, J. G. (1997). A study of brand equity in an organizational-buying context. Journal of Product \& Brand Management, $6(6), 428-439$.

Jalilvand, M. R., Salimipour, S., Elyasi, M., \& Mohammadi, M. (2017). Factors influencing word of mouth behaviour in the restaurant industry. Marketing Intelligence \& Planning, 35(1), 81-110.

Kang, G., Jame, J., \& Alexandris, K. (2002). Measurement of internal service quality: Application of the SERVQUAL battery to internal service quality. Managing Service Quality: An International Journal, 12(5), 278-291.

Khajeheian, D. (2016). Audience Commodification: A Source of Innovation in Business Models. Technology Innovation Management Review, 6(8), 8.

Kim, H. (2014). The role of WOM and dynamic capability in B2B transactions. Journal of Research in Interactive Marketing, 8(2), 84-101. https://doi.org/10.1108/JRIM-12-2013-0082

Klein, C., DeRouin, R. E., \& Salas, E. (2008). Uncovering workplace interpersonal skills: A review, framework, and research agenda. In G. P. Hodgkinson \& J. K. Ford (Eds.), International Review of Industrial and Organizational Psychology 2006 (pp. 79-126). John Wiley \& Sons, Ltd.

Kumar, A., \& Grisaffe, D. B. (2004). Effects of extrinsic attributes on perceived quality, customer value, and behavioral intentions in B2B settings: A comparison across goods and service industries. Journal of Business-to-Business Marketing, $11(4), 43-74$.

Lai, F., Hutchinson, J., Li, D., \& Bai, C. (2007). An empirical assessment and application of SERVQUAL in mainland China's mobile communications industry. International Journal of Quality \& Reliability Management, 24(3), $244-262$.

Lang, B., \& Lawson, R. (2013). Dissecting Word-of-Mouth's Effectiveness and How to Use It as a Proconsumer Tool. Journal of Nonprofit \& Public Sector Marketing, 25(4), 374-399.

Lee, C.-C., Cheng, H. K., \& Cheng, H.-H. (2007). An empirical study of mobile commerce in insurance industry: Tasktechnology fit and individual differences. Decision Support Systems, 43(1), 95-110.

Mokhtaran, M., Fakharyan, M., Jalilvand, M. R., \& Mohebi, M. (2015). The Effect of Service Climate on Perceived Service Value and Behavioral Intentions: The Mediating Role of Service Quality. Asia Pacific Journal of Tourism Research, 20(4), $472-486$.

Nasr, N., Eshghi, A., \& Ganguli, S. (2012). Service Quality in Hybrid Services: A Consumer Value Chain Framework. Journal of Services Research, 12(1), 115-130.

Nyadzayo, M. W., \& Khajehzadeh, S. (2016). The antecedents of customer loyalty: A moderated mediation model of customer relationship management quality and brand image. Journal of Retailing and Consumer Services, 30, $262-270$.

Pallant, J. (2005). SPSS survival manual: A step by step guide to using SPSS for windows (version 12). New South Wales, Australia: Allen \& Unwin.

Parasuraman, A., Zeithaml, V. A., \& Berry, L. L. (1985). A Conceptual Model of Service Quality and Its Implications for Future Research. Journal of Marketing, 49(4), 41-50.

Parasuraman, A., Zeithaml, V. A., \& Malhotra, A. (2005). E-S-QUAL: A Multiple-Item Scale for Assessing Electronic Service Quality. Journal of Service Research, 7(3), 213-233.

Parasuraman, A, Zeithaml, V., \& Berry, L. (2002). SERVQUAL: a multiple-item scale for measuring consumer perceptions of service quality. Retailing: Critical Concepts, 64(1), 140.

Parasuraman, Arun, Berry, L. L., \& Zeithaml, V. A. (1991). Refinement and reassessment of the SERVQUAL scale. Journal of Retailing, 67(4), 420.

Preacher, K. J., \& Hayes, A. F. (2008). Asymptotic and resampling strategies for assessing and comparing indirect effects in multiple mediator models. Behavior Research Methods, 40(3), 879-891.

Ohlsson, E., \& Johansson, B. (2010). Non-life insurance pricing with generalized linear models (Vol. 21). Springer.

Rentz, J. O., Shepherd, C. D., Tashchian, A., Dabholkar, P. A., \& Ladd, R. T. (2002). A measure of selling skill: Scale development and validation. Journal of Personal Selling \& Sales Management, 22(1), 13-21. 
Roth, P., Bobko, P., McFarland, L., \& Buster, M. (2008). Work sample tests in personnel selection: A meta-analysis of blackwhite differences in overall and exercise scores. Personnel Psychology, 61(3), 637-661.

Sánchez, J., Callarisa, L., Rodríguez, R. M., \& Moliner, M. A. (2006). Perceived value of the purchase of a tourism product. Tourism Management, 27(3), 394-409.

Santos, J. (2003). E-service quality: A model of virtual service quality dimensions. Managing Service Quality: An International Journal, 13(3), 233-246.

Seth, N., Deshmukh, S. G., \& Vrat, P. (2005). Service quality models: A review. International Journal of Quality \& Reliability Management, 22(9), 913-949.

Shamma, H. M. (2012). Toward a comprehensive understanding of corporate reputation: Concept, measurement and implications. International Journal of Business and Management, 7(16), 151.

Sharma, A., \& Mehta, V. (2004). Service quality perceptions in financial services-a case study of banking services. Journal of Services Research, 4(2), 205.

Sharma, P., Tam, J. L. M., \& Kim, N. (2009). Demystifying Intercultural Service Encounters: Toward a Comprehensive Conceptual Framework. Journal of Service Research, 12(2), 227-242.

Silverman, G. (2011). Secrets of word-of-mouth marketing: How to trigger exponential sales through runaway word of mouth. Amacom books.

Simons Jr, J. V. (2004). Reliability-based analysis of service recovery. International Journal of Quality \& Reliability Management, 21(1), 11-31.

Sweeney, J. C., Soutar, G. N., \& Mazzarol, T. (2008). Factors influencing word of mouth effectiveness: Receiver perspectives. European Journal of Marketing, 42(3/4), 344-364.

Tan, B.-I., Wong, C.-H., Lam, C.-H., Ooi, K.-B., \& Ng, F. C.-Y. (2010). Assessing the link between service quality dimensions and knowledge sharing: Student perspective. African Journal of Business Management, 4(6), 1014.

Taylor, S. A., Celuch, K., \& Goodwin, S. (2002). Technology readiness in the e-insurance industry: An exploratory investigation and development of an agent technology e-consumption model. Journal of Insurance Issues, $142-165$.

Thiruvattal, E., Petrovici, D., \& Alcaraz, J. M. (2013). Progressives, loyalists, multinationals, and newcomers: Clusters for targeting organisational customers of insurance. Journal of Services Research, 13(1), 31.

Walther, J. B. (1996). Computer-Mediated Communication: Impersonal, Interpersonal, and Hyperpersonal Interaction. Communication Research, 23(1), 3-43.

Walther, J. B. (2007). Selective self-presentation in computer-mediated communication: Hyperpersonal dimensions of technology, language, and cognition. Computers in Human Behavior, 23(5), 2538-2557.

Walther, J. B. (2011). Theories of computer-mediated communication and interpersonal relations. The Handbook of Interpersonal Communication, 4, 443-479.

Wangenheim, F., \& Bayón, T. (2004). The effect of word of mouth on services switching: Measurement and moderating variables. European Journal of Marketing, 38(9/10), 1173-1185.

Wangenheim, F. V. (2005). Postswitching negative word of mouth. Journal of Service Research, 8(1), 67-78.

Wilson, A., Zeithaml, V., Bitner, M. J., \& Gremler, D. (2016). Services marketing: Integrating customer focus across the firm.

Wolfinbarger, M., \& Gilly, M. C. (2001). Shopping online for freedom, control, and fun. California Management Review, 43(2), 34-55.

Yang, Z., Jun, M., \& Peterson, R. T. (2004). Measuring customer perceived online service quality: Scale development and managerial implications. International Journal of Operations \& Production Management, 24(11), 1149-1174.

Yavas, U., Benkenstein, M., \& Stuhldreier, U. (2004). Relationships between service quality and behavioral outcomes: A study of private bank customers in Germany. International Journal of Bank Marketing, 22(2), 144-157.

Zeithaml, Valarie A., Berry, L. L., \& Parasuraman, A. (1996). The Behavioral Consequences of Service Quality. Journal of Marketing, 60(2), 31-46.

Zeithaml, Valarie A, Parasuraman, A., \& Malhotra, A. (2002). Service quality delivery through web sites: A critical review of extant knowledge. Journal of the Academy of Marketing Science, 30(4), 362-375.

Zhang, J., Jiang, Y., Shabbir, R., \& Zhu, M. (2016). How brand orientation impacts B2B service brand equity? An empirical study among Chinese firms. Journal of Business \& Industrial Marketing, 31(1), 83-98.

Zhao, M., \& Xie, J. (2011). Effects of Social and Temporal Distance on Consumers' Responses to Peer Recommendations. Journal of Marketing Research, 48(3), 486-496.

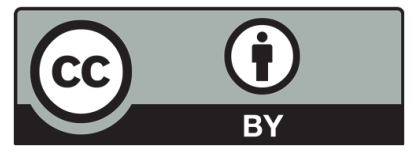

(C) 2021 by the authors; licensee Growing Science, Canada. This is an open access article distributed under the terms and conditions of the Creative Commons Attribution (CC-BY) license (http://creativecommons.org/licenses/by/4.0/). 